\title{
ABOUT SOME TRADITIONS AND PEOPLE OF SOUTH URALS IN RUSSIAN FEDERATION
}

Liudmila Guseva, Associate Professor, Ph.D. Eugenii Sergeev, Magister's Candidate lana Tiatiushkina, Magister's Candidate Nosov Magnitogorsk State Technical University - NMSTU, Magnitogorsk, Russia

\begin{abstract}
This article overviews some cultural and religious traditions of the people of Russian Federation and traces their history and their impact on modern society. The social class of Cossacks that formed the basis of the population of South Urals is briefly described in the historical retrospective.
\end{abstract}

Keywords:tradition, holidays, Cossacks, South Urals.

Resumo: Este artigo revê algumas tradições culturais e religiosas do povo da Federação Russa e traça a sua história e seu impacto na sociedade moderna. A classe social dos cossacos que formou a base da população do sul dos Urais é descrito brevemente na retrospectiva histórica.

Palavras-chave:tradição, feriados, cossacos, Urais do sul. 
The people of Russia have rich culture, folklore and century old traditions. Tradition is a mechanism for the maintenance, transfer and consolidation of social experience, a way to implement sustainable public relations [3, p. 43]. Many old traditions are alive at present time. Most of them are family traditions connected with children's birth, christenings, weddings and funerals. For example, popular traditions are paying the ransom for a bride or the mock kidnapping of a bride. Modern Russia has also unusual holidays which are not celebrated in other countries. Holiday traditions are remembered in detail across the generations. They provide opportunities to keep old Russian traditions.

For instance, 'Maslenitsa' is a Russian holiday of the beginning of spring. On one hand, Maslenitsa is a remembrance day of the dead. That's why Russians cook 'bliny' (Russian pancakes) as a good tradition. On the other hand, Russians ancestors associated this holiday with the coming of the spring. On this day people burn a scarecrow symbolizing the end of winter. People always have fun, sing songs and take part in different activities outdoors, like sledging and skating.

The whole Maslenitsa Week is divided into two periods: the "narrow" Maslenitsa (the first three days: Monday, Tuesday, Wednesday), and the "wide" Maslenitsa (the latter four days: Thursday, Friday, Saturday and Sunday).

For the first three days people could do some household duties, but from Thursday until Sunday they don't do the housework at all. Every day has its name during the Maslenitsa.Monday is the Greeting. People begin making Russian bliny. The first pancakes are given to the poor in remembrance of the dead. It is the day when the Lady Maslenitsa would be made of straw, old clothes and other burning materials. Tuesday is the Playing. In the past it was a day of the bride-show. All Maslenitsa traditions were connected with the matchmaking. It was necessary to get married after the Lent on 'Krasnaya Gorka' (Red Hill Holiday - a Sunday after the Easter, traditional time for couples to get married). In the morning, young people invited relatives and friends to go sledging and to eat bliny. Wednesday is the Sweet Tooth Day. On Wednesday the son-in-law is invited to eat the mother-in-law's bliny. The mother-in-law would show her love and care for him. Thursday is the Revelry (the Feast). It is the start of the "wide" Maslenitsa when all work stop and celebrations start widely. People used to entertain themselves, in the past they enjoy the horse-riding and fisticuffs, nowadays - the ice-skating and other snow activities. The must-do of the day is the attack on the Criar Educação, Criciúma, v. 6, nº1, julho/novembro 2016.- PPGE - UNESC 
Revista do Programa de Pós-Graduação em Educação - UNESC

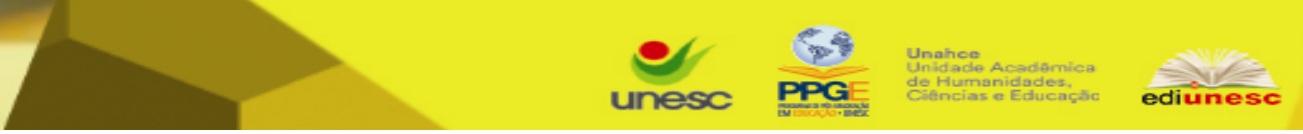

ice-house. The idea of the day is to let go of all the negative feelings and resolve all conflicts. People also make bonfires and jump over them. Friday is the Mother-in-law's Eve. On Friday mothers-in-law visit their sons-in-law for bliny. Her daughter, son-inlaw's wife, has to make them. The son-in-law shows his love to his mother-in-law and her relatives. Saturday is the Sister-in-law's Gathering. On Saturday young wives invited her husband's sisters-in-law and his other relatives. Sunday is the Forgiveness Day. It is a culmination of the Maslenitsa Week. All relatives ask forgiveness from their nearest and dearest for any wrongdoings or grievances that might have happened over the year. In the evening, Russians pray for people who have died. They go to the Russian hot steam bathing house, 'banya'. The climax of the holiday week is burning the Lady Maslenitsa. Its ashesare scattered at the fields. During Maslenitsa special races and shootings were organized. Children fired toy guns which adults would have made with animals long bones.

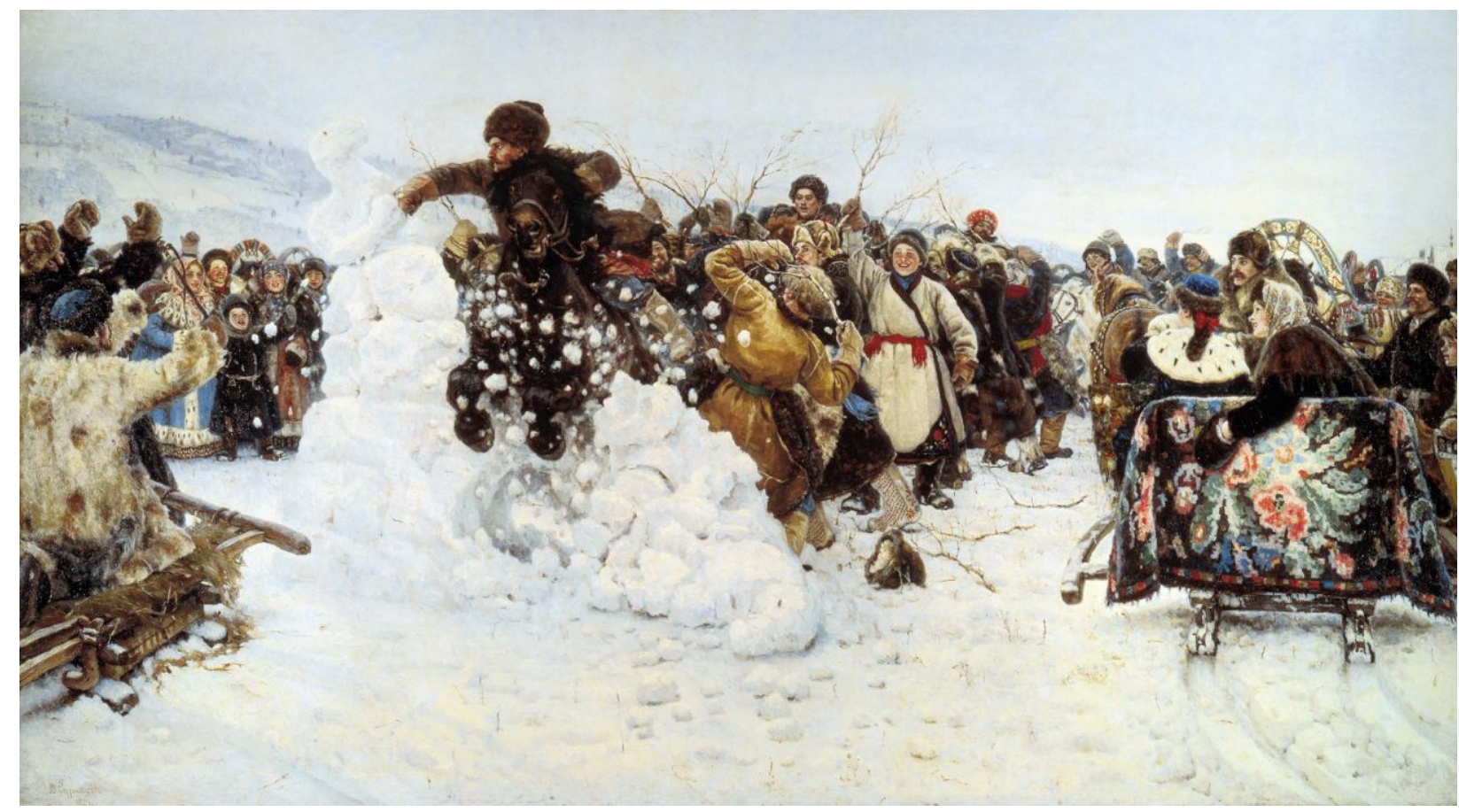

V.I. Surikov, The attack on a snow-fortress(1891)

https://upload.wikimedia.org/wikipedia/commons/thumb/3/34/SurikovSnowFortress.jpg/1 024px-SurikovSnowFortress.jpg 


\section{Unesc PPG}

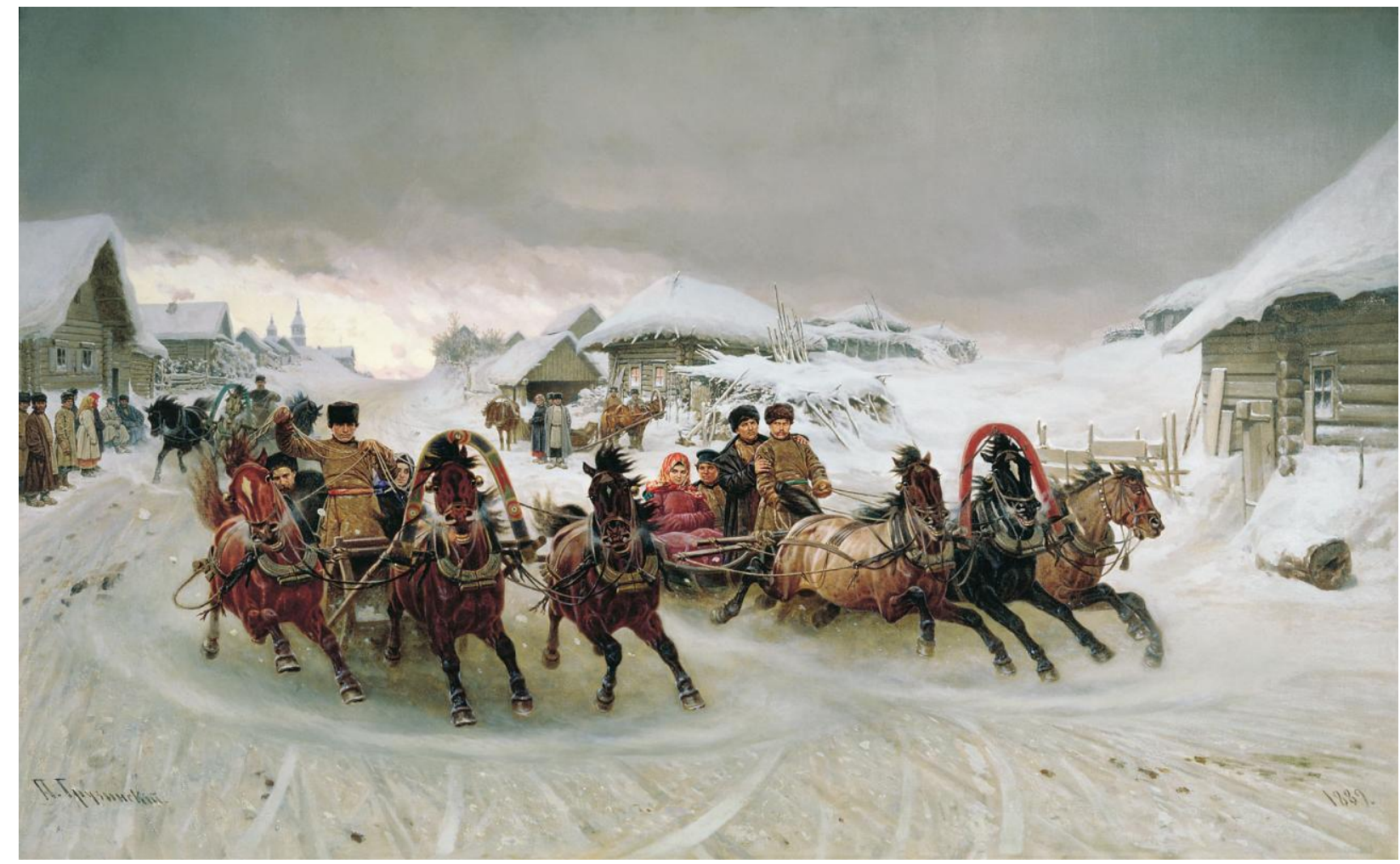

P.N. Gruzinskiy,

Maslenitsahttps://upload.wikimedia.org/wikipedia/commons/a/ad/Pyotr Nikolayevich $\mathrm{Gr}$ uzinsky - Maslenitsa.jpg

There are many ancient Russian ceremonies and customs which have connections with the death and funerals. The funeral ceremony was also as important Criar Educação, Criciúma, v. 6, nำ, julho/novembro 2016.- PPGE - UNESC 
as the organization of weddings and christenings. In the Slavic settlements there was a custom of placing big copper coins on the eyes of the dead. Otherwise, the dead could find a victim and put him into the grave. "Do not speak ill of the dead" is a well-known saying, however. This phrase was commonly used by our ancestors centuries ago because they thought that departed souls were together with them and could take revenge on people for the offensive words. It is thought to be necessary to cover the house mirrors when someone passed away.

Many ancient common traditions are kept today. For example, it is considered to be necessary, to let a cat into a new home first (this animal symbolizes a house-spirit). Because of the house-spirit it is also a bad custom to say "hello" and "goodbye" across the house threshold. The familiar spirit lives only in this house, but outside there is a power of other spirits which can spoil one's attitude with a person. The horseshoe is placed above the front door as the God Sun's protection. According to the orthodox traditions, people decorate the house with pussy-willow branches on the Palm Sunday, and with the leaves or herbs on the Trinity.

There are many traditions among interesting and respected people of our town. They are representatives of the Cossacks. It is a social group, which originally appeared a military class defending remote areas of our country, such as South Urals, in the 1517 th centuries. In the past, two thirds of the Chelyabinsk region ('oblast') used to be the Cossacks' territories. In the $19^{\text {th }}$ century, the Cossacks of South Urals had special rights and privileges. They were quite rich, so, they could build churches and schools in the Cossack villages ('stanitsa'). The main economic activities were agriculture and cattlebreeding. The Cossacks liked horses which they used as a cavalry and in the field work. The horse was a center of the Cossacks' life.

The administrative and territorial division of the Chelyabinsk oblast began in the $17^{\text {th }}$ century. It continued the politics of Peter the Great of expanding the borders and developing the industrial production of Russia. Therefore, the Isetsky Province was formed and Chelyabinsk city was its center. In the second half of the $18^{\text {th }}$ century the industry of South Urals actively developed. New towns (Zlatoust, Satka, Miass, Nyazepetrovsk) were built near the factories. By the special order of the Empress Elizaveta there appeared irregular troops in Orenburg fortress and the institute of military atamans was introduced. By the end of the $17^{\text {th }}$ century the Cossacks has formed the military class. After this time, the attacks of the wondering tribes were Criar Educação, Criciúma, v. 6, nำ, julho/novembro 2016.- PPGE - UNESC 
stopped. This was the start of intensive colonization of the vast forests and mountains of South Urals by Russian peasants and workers.

The major historic event was Pugachev's uprising when in February of 1774 Emelyan Pugachev's militants occupied Chelyabinsk, but the regular army eventually restored the order at the Ural factories. The Cossacks' affairs were the ataman's business. Most Chelyabinsk's citizens in the $17^{\text {th }}$ century were Cossacks. That's why the ataman's power has spread over all citizens.

In the $19^{\text {th }}$ century new settlements, such as Varna, Fershampenuaz, Borodino, Paris, appeared in South Urals. Their names are given by the places of the Russian army's victories. For instance, village Varna was called in honor of the capture of Bulgarian fortress Varna in 1828 during the first war with Ottoman Empire. The historical term South Urals includes Chelyabinskya oblast, Orenburgskaya oblast, Kurganskaya oblast, Baskiriya, a part of Sverdlovskaya oblast and the Southern part of Kazahstan. All these territories at the end of the $17^{\text {th }}$ and the beginning of the $19^{\text {th }}$ century were a part of large Orenburgskaya Province.

One of the oldest Cossacks' traditions in South Urals, connected with the young men's preparation for the army, was military games. The groups of young men (20-30) with an ataman and elderly people used to come to certain meeting place. They rode horses and had necessary armaments like a pike, gun, saber and other equipment. The camp was organized on a valley. Young Cossacks were divided into detachments and all detachments performed various exercises. Some participants took part in horse racing, while others practiced shooting at marks or demonstrated their abilities to fight with a saber or a gun while riding a horse. One of the feats was to pick up an object, e.g., a lash or a coin, from the ground at the horse's full gallop.

There were competitive duels among the Cossacks. Most brave men had a real fight. They also demonstrated their ability to cross the river as quickly as possible while riding a horse. In the evenings on the competitive days there were the fisticuffs. Young people went to the hand-to-hand fighting to show their hardiness, braveness, strength, and ability to defend themselves and their detachments. Minor injures didn't matter as the victory was priceless. The fights results were announced by the ataman. He awarded the winners in different competition categories. Awards were bridles, saddle accessories, armaments, etc. After the war games, the young Cossacks called-up to the army invited relatives for the farewell party.

Criar Educação, Criciúma, v. 6, nำ1, julho/novembro 2016.- PPGE - UNESC 
The Cossacks celebrated all Orthodox feasts. The Christmas tradition was riding the sledge. Children used to ride 'ice-boats', special baskets iced with water in open cold air. People rode 'troika' (three horses harnessed abreast) and played different games.

The Easter was the most bright spring holiday with many entertainments. Celebrations started from the Palm Sunday. This day was a special one for children. In provinces and towns the fairs with various performances were organized. People used to buy clothes and presents for children. Children were slapped slightly across the face with pussy-willow branches. This action had a healthful power because pussy-willow branches made children sneeze and cry, and the child's health was renewed. All people took part in the Easter preparations. They cooked the Easter cake. There were a lot of games.

The Cossacks also celebrated the Trinity. It was the Orthodox holiday connected with the plants as a symbol of the growth. During Trinity there were the card-reading about future husbands, songs with the marriage prayer. There was also the Midsummer Night when girls formed a roundelay, jumped over the bonfire, looked for 'the flowers of fern'. The clergymen sanctified water in the wells. It was also time to collect medical herbs.

In autumn, there were customs connected with harvesting. It was forbidden to go to the forest before the fruits are ripe. At certain days it was allowed to collect fruits, berries and honey. In South Urals there was the celebration of a holy day of the Protection of the Most Holy Mother of God. After the Cossacks finished the works in fields, they started organizing the weddings. It was a very important ritual which lasted 2 days. It has many components, the elements of material world (clothes, hats, wedding carriages and home decorations), folklore and music.

The freedom-loving Cossacks loved their homeland. The patriotic love for the country was associated with love for the fatherland, the Urals. The basis of their faith was the idea of love for own people. The originality of the Cossacks class was based on their spirituality and on the combination of their moral and ethic values. The Cossacks' respect for family life changed the attitude towards women. The Cossack was usually out of home for war, work or land's exploration. Therefore, women had to care about the family, do the housework and be ready to protect home in danger. Because of thus the 


\section{CRIAR EDUCAÇÃO}

Revista do Programa de Pós-Graduação em Educação - UNESC

new type of women appeared in South Urals. They were hard-working and brave, they were ready to do man's work.

Today the Cossacks class is revived as a social and cultural unit of Russian society. It is a formation the Cossacks as a new ethnos. There are attempts to look at the history and to discover who the Cossacks were and what role they played in Russian history. Mental and moral upbringing is based on the traditions. It is one of the ways to improve the educational content by teaching the younger generation to appreciate family and cultural traditions with the help of ceremonies, art, handcrafts. 


\section{CRIAR EDUCAÇÃO}

Revista do Programa de Pós-Graduação em Educação - UNESC

\section{References:}

1. Bakhtin, M.M. Aesthetics of verbal art/ Bakhtin - M. : Art, 1979. - 423 p.

2. Chugunov, S.M. The history of the Cossacks on the Ural. - Orenburg, 2003. $232 \mathrm{p}$.

3. Guseva, L.G.Ethnopedagogy and intercultural communication in higher education. -Modern developmental psychology: main trends and prospects of research : materials of the international scientific conference on October 20-21, 2015. Prague :Vědeckovydavatelské centrum «Sociosféra-CZ», 2015. - 194 p. - ISBN 97880-7526-053-6 Pp. 104-108.

4. Krivoshekov, A.I. Ceremonies and customs of Orenburg Cossacks / A.I. Krivoshekov // Bulletin of Orenburg educational region. - 1915. № 1,2,3,4,5,6,7http://credonew.ru/content/view/571/31/

5. http://forum1.kazakia.info/viewtopic.php? $p=1143$

Authors:

\section{Prof. LiudmilaGuseva}

$\mathrm{PhD}$ in Education. Associate Professor

Nosov Magnitogorsk State Technical University

Magnitogorsk, Chelyabinsk region, Russian Federation

Eugenii Sergeev, Magister's Candidate

Nosov Magnitogorsk State Technical University

Magnitogorsk, Chelyabinsk region, Russian Federation

lana Tiatiushkina, Magister's Candidate

Nosov Magnitogorsk State Technical University

Magnitogorsk, Chelyabinsk region, Russian Federation 